\title{
Aplastic anaemia and the hypocellular myelodysplastic syndrome: histomorphological, diagnostic, and prognostic features
}

\author{
INGRID FOHLMEISTER, ${ }^{*}$ R FISCHER, ${ }^{*}$ B MÖDDER, $\dagger$ M RISTER, $\ddagger$ H-E SCHAEFER§ \\ From the *Institute of Pathology of the University of Köln, the Departments of †Internal Medicine II and \\ $\ddagger$ Pediatrics of the University Clinics of Köln, and the §Institute of Pathology of the University of Freiburg, \\ West Germany
}

SUMMARY In a retrospective study of 111 patients with aplastic anaemia iliac crest biopsies were evaluated for the presence of morphological features statistically related to the evolution of the disease. Prognostic variables for a transition to acute non-lymphatic leukaemia were: cellular atypias of the three haemopoietic lineages, as observed in the myelodysplastic syndrome, and especially "micromegakaryocytes"; high numbers or irregular distribution of megakaryocytes, or both; and (slight) marrow fibrosis. Clinical variables did not influence these prognostic correlations. Prognosis in relation to death from bone marrow failure without leukaemia might well have been influenced by a strong plasma cell reaction, but this correlation was weakened by clinical factors. On the basis of this study aplastic anaemia can thus be subdivided morphologically into two disease entities - namely, hypocellular myelodysplastic syndrome with a 23-82\% risk of acute non-lymphatic leukaemia developing within three years, depending on how many variables associated with acute non-lymphatic leukaemia are present, and non-dysplastic myelohypoplasia.

The incidence of transition to acute non-lymphatic leukaemia from aplastic anaemia has often been discussed. ${ }^{-7}$ New light has been thrown on this controversy by the recognition of a hypocellular form of the myelodysplastic syndrome $e^{8-12}$ and, in particular, by certain characteristic morphological abnormalities seen in the myelodysplastic syndrome that have also been reported in patients with aplastic anaemia. ${ }^{7314}$ Aplastic anaemia is known to be heterogeneous in terms of aetiology and pathogenesis. $^{15-17}$ It may well include, therefore, entities with a different pathogenetic relation to acute non-lymphatic leukaemia.

The myelodysplastic syndrome, which has a propensity to develop into acute non-lymphatic leukaemia, has been shown to be a clonal stem cell disorder. ${ }^{18-20}$ Clonal analysis ${ }^{20} 21$ would therefore be the method of choice to investigate this question. The application of genetic methods, however, is often hampered in aplastic anaemia by the lack of haemopoietic cells. ${ }^{4}$ We therefore screened routinely obtained iliac crest biopsies from patients

Accepted for publication 29 May 1985 with aplastic anaemia for histological features associated with the development of acute nonlymphatic leukaemia or death due to bone marrow failure without leukaemia, or both.

\section{Material and methods}

\section{SELECTION OF BIOPSIES}

Iliac crest biopsies done at the Institute of Pathology (Unversity of Cologne) between January 1968 and July 1981 were reviewed for hypocellular marrow. Biopsies from patients with hepatosplenomegaly, deficiencies, or metabolic or storage diseases and patients who have undergone cytotoxic or radiation treatment during the previous 24 months were excluded, as were biopsies with metastases or blast cell infiltration. Only biopsies with a minimum length of $15 \mathrm{~mm}$ were evaluated. A total of 111 cases were found.

\section{FOLLOW UP OF PATIENTS}

Patients were followed up until October 1982. Follow up included cytological or histological bone marrow examination, or both. No further examin- 
ation of the bone marrow from the three patients who died within one week was performed. By the end of follow up 20 patients had developed acute non-lymphatic leukaemia (within one to 45 months) and 33 had died from bone marrow failure without acute non-lymphatic leukaemia (within one day to 78 months). Thirty five patients were lost to follow up-that is, after two to 26 months. For these patients the day of the last bone marrow examination was taken as the day of loss. Twenty three patients survived without developing acute nonlymphatic leukaemia during follow up - that is, they survived for periods ranging from 15 months to more than 11 years. No patients died of an unrelated illness.

\section{DEFINITION OF OVERT LEUKAEMIA}

According to the proposals of the FAB cooperative group, for a diagnosis of acute non-lymphatic leukaemia more than $30 \%$ blasts are required in the bone marrow smear. In three cases, in which the bone marrow was controlled only by biopsy, large confluent blast nests were taken as an indication of "overt" leukaemia.

\section{CLINICAL DATA}

At the time of the biopsy 79 patients had pancytopenia, five had anaemia or neutropenia, nine had anaemia or thrombopenia, eight had thrombopenia or leukopenia, and 10 had isolated anaemia. Six patients had only a few peripheral blasts (1-4\%). Fifty five patients had a history of exposure to drugs or industrial chemicals. These were chloramphenicol (one); benzol (two); gold (one); phenylbutazone (five); multiple analgesics (29); tranquillisers (three); sulphonamide derivatives (seven); cytotoxic treatment 13 and two and a half years previously (two); multiple industrial solvents (two); and alcohol (three). Four children had Fanconi's anaemia. Viral factors were implicated in eight cases, immunological factors in three, and hormonal factors in one. Aetiological factors were not found in 35 patients, and information was not available in five cases.

\section{PROCESSING OF BIOPSIES}

Biopsies were fixed and decalcified as previously described. ${ }^{22}$ After conventional paraffin embedding, dewaxed sections $3 \mu \mathrm{m}$ thick were routinely stained as follows: Giemsa; periodic acid Schiff, Perl's reaction for iron; Gömöri's silver impregnation; and naphthol-AS-D-chloracetate esterase reaction.

EVALUATION OF QUANTITATIVE

MORPHOLOGICAL FEATURES

Marrow cellularity was determined at a magnification of 250 using the point-hit method (800 points) with a Zeiss integration plate II. The measured values, with relative volumes expressed as percentages, were adjusted for age. ${ }^{23}$ Included in the study were biopsies with a marrow volume below the normal range ${ }^{23}$ and three biopsies within the lower normal range that showed pronounced lymphocytic infiltration. Megakaryocytes and tissue mast cells were counted at a magnification of 400 with a $10 \times 10 \mathrm{~mm}$ grid ocular.

\section{STATISTICAL METHOD}

Recently, the actuarial survival time method has been used in combination with multiple retrospective stratification ${ }^{24}$ as a refined method of isolating prognostic variables in the myelodysplastic syndrome that are related to death. ${ }^{25}$ This method was used in an almost identical manner in our study. The variables were analysed, however, for their relation to two more specific prognostic "events": transition to acute non-lymphatic leukaemia and death due to bone marrow failure without leukaemia. The variables were subdivided into classes of values. For each class the statistically expected number $(E)$ for the occurrence of a certain "event" was compared with the observed number $(\mathrm{O})$ of these events by means of the log rank test. ${ }^{24}$ Variables apparently correlated with prognosis (as defined above) were tested by retrospective stratification to see whether the prognostic correlation was independent or due to an association with one or more, and possibly more important, prognostic factor(s). For this purpose the initial screening for prognostic factors had to be extended to clinical variables.

\section{Results}

In some cases conspicuous qualitative changes and a distinctly irregular distribution of haemopoietic cells were noticed. Most striking were the megakaryoctye abnormalities. Small cell forms with asynchrony of maturation between nucleus and cytoplasm, so called "micromegakaryocytes," were typical (Figs. $1,2 \mathrm{a})$. The nuclei were often rounded or bilobulated (Figs. 1a, b) but sometimes had developed bizarre hypersegmentation and irregular condensation of chromatin (Figs. 1e-g). Additional features were nuclear budding and fragmentation (Figs. 1c, e-g), as well as atypical mitoses. The maturation of the cytoplasm had sometimes been delayed. Mature eosinophil granulated foci within an otherwise immature basophilic cytoplasm and clumping of granules were very characteristic (Figs. 1d, f; 2a). In most cases megakaryocytic abnormalities were associated with increased numbers of megakaryocytes and an irregular distribution in small clusters 


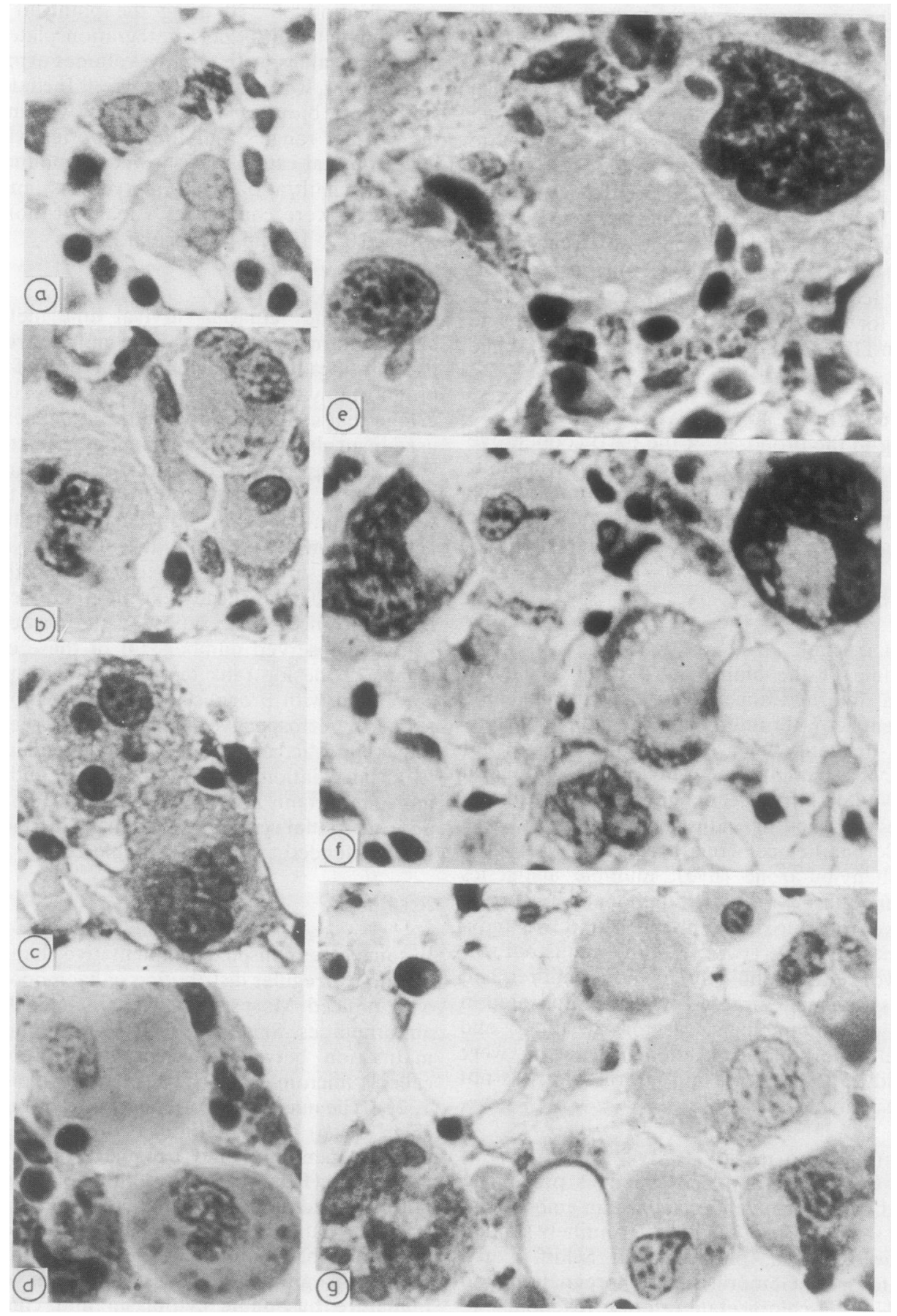

Fig. 1 Features of dysmegakaryopoiesis in biopsy (Giemsa, periodic acid Schiff.) $\times 1000$. 


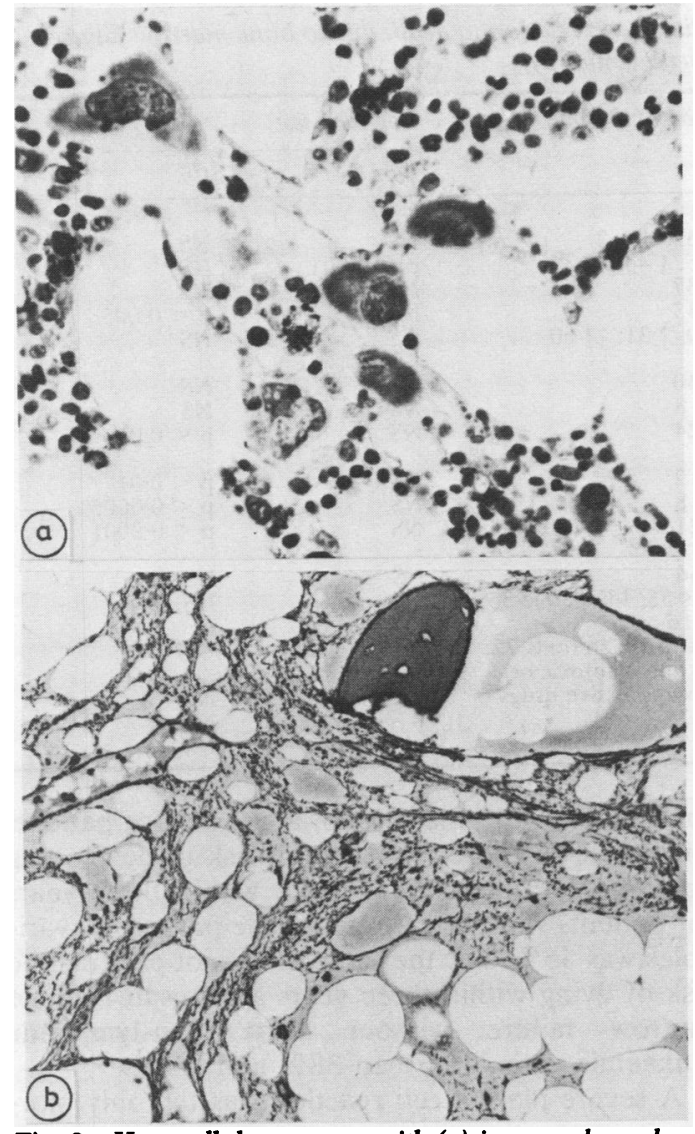

Fig. 2 Hypocellular marrow with (a) increased numbers and clustering of atypical megakaryocytes (Giemsa) $\times 375$ and (b) focal reticulin fibrosis (Gömöri) $\times 250$.

(Fig. 2a). Sometimes, however, the megakaryocytes were abnormal but reduced in number, or essentially normal megakaryocytes showed focal clustering.

In virtually all cases granulopoiesis and ery- thropoiesis exhibited a certain degree of maturation arrest. Severely arrested maturation and more specific features indicating dysmyelopoiesis of these cell lines, such as megaloblastosis, sideroblastosis, and Pelger like cells, were rare. Dyserythropoiesis and dysgranulopoiesis were histologically visible only if very severe but were cytologically visible in a much larger proportion of cases. They were usually found in combination with dysmegakaryopoiesis.

Dysmegakaryopoiesis was often associated with argyrophilic marrow fibrosis. Usually there was only a subtle increase in reticulin fibres and their distribution was patchy. Few patients had moderately patchy or distinctly diffuse fibrosis (Fig. 2b). Collagen fibrosis was not present. There were also cases of marrow fibrosis with no sign of dysmyelopoiesis.

Other differences between the biopsies were the so called "inflammatory" changes. These consisted of lymphocytic, plasmocytic, and mast cell infiltration, as well as marrow oedema and haemorrhage in varying combinations, and seemed to be independent of the dysmyelopoietic changes.

Of the described morphological features, dysmyelopoiesis of all three cell lines, irregular distribution and high numbers of megakaryocytes, as well as marrow fibrosis were all of prognostic value for the development of acute non-lymphatic leukaemia but not for death due to bone marrow failure (Tables 1 and 2). The prognostic power of these features was not weakened by clinical factors, none of which correlated with transition to acute non-lymphatic leukaemia. Dysmegakaryopoiesis showed the strongest correlation with the development of acute non-lymphatic leukaemia. Fourteen of 21 patients with megakaryocytic atypias developed acute nonlymphatic leukaemia as opposed to six of 90 without this feature (Fig. 3). When the number of prognostic variables associated with the development of acute non-lymphatic leukaemia was taken into consideration, irrespective of their nature, the prognosis

Table 1 Quantitative variables studied for their prognostic significance in relation to death due to bone marrow failure without leukaemia (a) and development of acute non-lymphatic leukaemia (b).

\begin{tabular}{|c|c|c|c|c|c|}
\hline \multirow[t]{2}{*}{ Variables } & \multirow{2}{*}{$\begin{array}{l}\text { No of } \\
\text { patients }\end{array}$} & \multirow{2}{*}{$\begin{array}{l}\text { Range of } \\
\text { values }\end{array}$} & \multirow[t]{2}{*}{ Median } & \multicolumn{2}{|c|}{ Log rank test } \\
\hline & & & & (a) & (b) \\
\hline $\begin{array}{l}\text { Morphological: } \\
\text { Haemopoietic marrow (vol \%) } \\
\text { Megakaryocytes/ } \mathrm{mm}^{2} \\
\text { Tissue mast cells } / \mathrm{mm}^{2}\end{array}$ & $\begin{array}{l}111 \\
111 \\
111\end{array}$ & $\begin{array}{l}0-50 \\
0-202 \\
0-205\end{array}$ & $\begin{array}{l}29 \cdot 3 \\
12 \\
53\end{array}$ & $\begin{array}{l}\text { NS } \\
\text { NS } \\
\text { NS }\end{array}$ & $\begin{array}{l}\text { NS } \\
\text { p }<0.025 \\
\text { NS }\end{array}$ \\
\hline $\begin{array}{l}\text { Clinical: } \\
\text { Age (years) } \\
\text { Haemoglobin }(g / 1) \\
\text { Red cells }\left(\times 10^{\prime 2} / 1\right) \\
\text { Neutrophils }\left(\times 10^{\circ} / 1\right) \\
\text { Platelets }\left(\times 10^{\circ} / 1\right) \\
\text { Circulating blasts }\left(\times 10^{\circ} / 1\right) \\
\end{array}$ & $\begin{array}{r}111 \\
110 \\
98 \\
108 \\
103 \\
111\end{array}$ & $\begin{array}{l}6-86 \\
38-171 \\
1 \cdot 1-5 \cdot 6 \\
0-7 \cdot 9 \\
1-368 \\
0-0.05\end{array}$ & $\begin{array}{c}56 \\
93 \\
2 \cdot 5 \\
1 \cdot 1 \\
48 \\
0\end{array}$ & $\begin{array}{l}\text { NS } \\
\mathrm{p}<0.01 \\
\mathrm{p}<0.005 \\
\mathrm{p}<0.025 \\
\text { NS } \\
\text { NS }\end{array}$ & $\begin{array}{l}\text { NS } \\
\text { NS } \\
\text { NS } \\
\text { NS } \\
\text { NS } \\
\text { NS }\end{array}$ \\
\hline
\end{tabular}


Table 2 Qualitative variables studied for their prognostic significance in relation to death due to bone marrow failure without leukaemia (a) and development of acute non-lymphatic leukaemia (b).

\begin{tabular}{|c|c|c|c|c|}
\hline \multirow[t]{2}{*}{ Variables } & \multirow{2}{*}{$\begin{array}{l}\text { No of } \\
\text { patients }\end{array}$} & \multirow[t]{2}{*}{ Distribution of patients } & \multicolumn{2}{|l|}{ Log rank test } \\
\hline & & & (a) & (b) \\
\hline \multicolumn{5}{|l|}{ Morphological: } \\
\hline $\begin{array}{l}\text { Lymphocytic infiltration } \\
\text { Plasma cell reaction } \\
\text { Marrow oedema or haemorrhage } \\
\text { Fibrosis } \\
\text { Siderin in reticulum cells } \\
\text { Irregular distribution of }\end{array}$ & $\begin{array}{l}111 \\
111 \\
111 \\
111 \\
111\end{array}$ & $\begin{array}{l}\text { - } 53 ;+55 ;++3 \\
\text { normal } 35 ; \uparrow 44 ; \uparrow \uparrow 32 \\
-74 ;+37 \\
-68 ;+43 \\
\text { normal } 20 ; \uparrow 31 ; \uparrow \uparrow 60\end{array}$ & $\begin{array}{l}\text { NS } \\
\text { p }<0.001 \\
\text { NS } \\
\text { NS }\end{array}$ & $\begin{array}{l}\text { NS } \\
\text { NS } \\
\text { NS } \\
\text { p }<0.005 \\
\text { NS }\end{array}$ \\
\hline $\begin{array}{l}\text { Erythropoiesis } \\
\text { Granulopoiesis } \\
\text { Megakaryopoiesis }\end{array}$ & $\begin{array}{l}111 \\
111 \\
111\end{array}$ & $\begin{array}{l}-71 ;+40 \\
-103 ;+8 \\
-87 ;+24\end{array}$ & $\begin{array}{l}\text { NS } \\
\text { NS } \\
\text { NS }\end{array}$ & $\begin{array}{l}\text { NS } \\
\text { NS } \\
\mathrm{p}<0.05\end{array}$ \\
\hline $\begin{array}{l}\text { Cellular atypias of: } \\
\text { Erythropoiesis } \\
\text { Granulopoiesis } \\
\text { Megakaryopoiesis } \\
\text { Clinical }\end{array}$ & $\begin{array}{l}111 \\
111 \\
111\end{array}$ & $\begin{array}{l}-99 ;+12 \\
-103 ;+8 \\
-90 ;+21\end{array}$ & $\begin{array}{l}\text { NS } \\
\text { NS } \\
\text { NS }\end{array}$ & $\begin{array}{l}\mathrm{p}<0.01 \\
\mathrm{p}<0.0005 \\
\mathrm{p}<0.0001\end{array}$ \\
\hline $\begin{array}{l}\text { Sex } \\
\text { Aetiology }\end{array}$ & $\begin{array}{l}111 \\
106\end{array}$ & $\begin{array}{l}\text { o } 45 \text {; } \$ 66 \\
\text { Exogenous } 55 \text {; Idiopathic } 35 \text {; } \\
\text { Others } 16\end{array}$ & $\begin{array}{l}\text { NS } \\
\text { NS }\end{array}$ & $\begin{array}{l}\text { NS } \\
\text { NS }\end{array}$ \\
\hline Treatment & 111 & $\begin{array}{l}\text { Symptomatic } 33 ; \text { steroids } 72 \text {; } \\
\text { steroids and cytotoxic or }\end{array}$ & & \\
\hline $\begin{array}{l}\text { Severe bleeding at time of biopsy } \\
\text { Severe infection at time of biopsy }\end{array}$ & $\begin{array}{l}108 \\
108\end{array}$ & $\begin{array}{l}-96 ;+12 \\
-90 ;+18\end{array}$ & $\begin{array}{l}\mathrm{p}<0.0005 \\
\mathrm{p}<0.0001\end{array}$ & $\begin{array}{l}\text { NS } \\
\text { NS }\end{array}$ \\
\hline
\end{tabular}

worsened as the number of prognostic variables increased (Fig. 4). Fifteen of 19 patients, however, with three or more prognostic variables showed evidence of dysmegakaryopoiesis, because dysmegakaryopoiesis was correlated with all the other prognostic variables.

The risk of developing acute non-lymphatic leukaemia within three years after diagnosis was $9 \%$ for patients without any prognostic features, $23 \%$

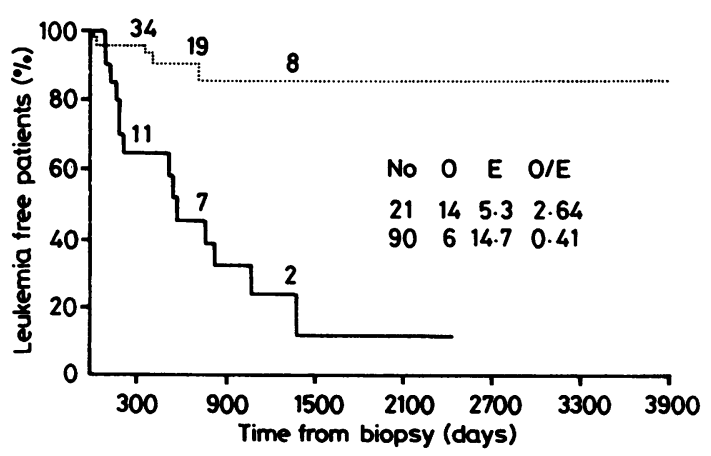

Fig. 3 Actuarial curves showing risk of aplastic anaemia developing into acute non-lymphatic leukaemia for patients with ( $\longrightarrow$ ) and without (. . . .) megakaryocytic atypias in iliac crest biopsy. Difference is.highly significant $\left(\chi^{2}=\right.$ 19.43; $d f=1 ; p<0.0001$ ). $O=$ observed number, $E=$ statistically expected number of cases of acute non-lymphatic leukaemia. Number of patients with no transition to acute non-lymphatic leukaemia and still under observation one, two, and four years after diagnosis is indicated on curves. for patients with one or two, and $82 \%$ for patients with three or more. The overall risk of developing acute non-lymphatic leukaemia within three years for patients with at least one of the prognostic variables was $45 \%$. For the same groups of patients the risk of dying within three years as a result of bone marrow failure without acute non-lymphatic leukaemia varied between $38 \%$ and $45 \%$.

A severe plasma cell reaction was the only mor-

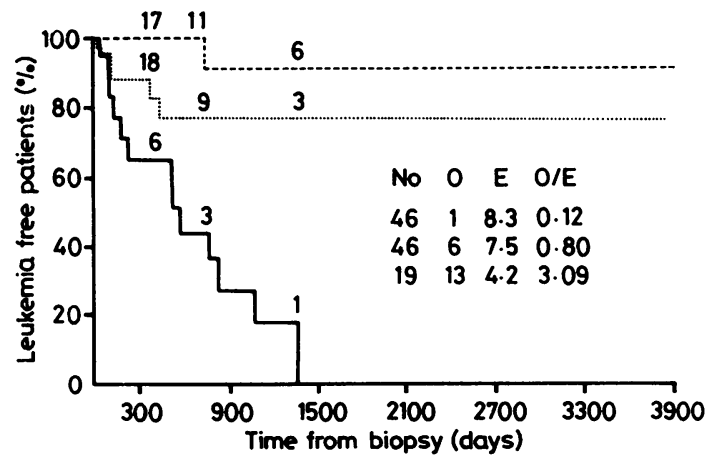

Fig. 4 Actuarial curves showing risk of aplastic anaemia developing into acute non-lymphatic leukaemia for patients with no (-...), with one or two (. . . .), and with three or more (—) of the morphological features correlated with development of acute non-lymphatic leukaemia. Difference is highly significant $\left(\chi^{2}=25 \cdot 11 ; d f=2 ; p<\right.$ $0.0001)$. $O=$ observed number, $E=$ statistically expected number of cases of acute non-lymphatic leukaemia.

Number of patients with no transition to acute

non-lymphatic leukaemia and still under observation one, two, and four years after diagnosis is indicated on curves. 
phological feature associated with death due to bone marrow failure (Tables 1 and 2), whereas several clinical variables correlated. With this severe bleeding and severe infection at the time of biopsy were most strongly related to this prognostic event. After retrospective stratification for these two factors the correlation of a severe plasma cell reaction with death due to bone marrow failure became less significant.

\section{Discussion}

The morphological evaluation of bone marrow biopsies allowed a distinction to be made in aplastic anaemia between two haemopoietic disorders that differ in their propensity to develop into acute nonlymphatic leukaemia but show an equally high risk of death due to bone marrow failure. Dysmyelopoiesis of all three cell lines, irregular distribution and high numbers of megakaryocytes, and marrow fibrosis all indicated an increased risk of a transition to acute non-lymphatic leukaemia. The cellular atypias shown here have been described as typical for the myelodysplastic syndrome with normocellular to hyperplastic marrow. ${ }^{18}{ }^{19}$ In a certain proportion of cases of aplastic anaemia with features associated with leukaemia hypercellular myelodysplastic syndrome develops before the transition to acute non-lymphatic leukaemia ${ }^{826}$ It seems reasonable, therefore, to classify this group of cases as hypocellular myelodysplastic syndrome and to distinguish them from aplastic anaemia with nondysplastic myelohypoplasia. The risk of developing acute non-lymphatic leukaemia within three years after diagnosis is then $45 \%$ for patients with hypocellular myelodysplastic syndrome-that is, within the range found so far for the different forms of the myelodysplastic syndrome ${ }^{192025}$-and as low as $9 \%$ for patients with the non-dysplastic form of aplastic anaemia.

Until now no attempt has been made to isolate prognostic factors for the transition from aplastic anaemia to acute non-lymphatic leukaemia, but circumstantial evidence supports a prognostic role for marrow fibrosis, dyserythropoiesis, high numbers of megakaryocytes, and severe lymphocytic infiltration. ${ }^{513}$ In our study, however, the highest prognostic value was found for megakaryocytic atypias. In contrast to the hypercellular forms of the myelodysplastic syndrome, dysgranulopoiesis and dyserythropoiesis were of lesser value. This was at least partly due to the fact that in myelohypoplasia they seldom reach the same intensity. Although often seen cytologically, ${ }^{14}$ they are detected histologically in only a few cases. The suspected prognostic value of the degree of lymphocytic infiltration' could no longer be found in our material after exclusion of cases with small blast cell nests. ${ }^{9}$

The correlation between plasma cell reaction and death due to bone marrow failure that we found in our investigation adds to the conflicting results documented previously.5 ${ }^{52728}$ Retrospective stratification suggests that the differences may partly be due to differences in the composition of the patient groups.

We thank all those colleagues who contributed single cases to the study.

\section{References}

Dameshek W. Riddle: what do aplastic anemia, paroxysmal nocturnal hemoglobinuria (PNH) and "hypoplastic" leukemia have in common? Blood 1967;30:251-4.

${ }^{2}$ Fischer R, Fohlmeister I. Pathology of panmyelophthisis (aplastic anemia). In: Lennert $\mathrm{K}$, ed. Histopathology of the bone marrow. Stuttgart: G Fischer, 1984:225-43.

${ }^{3}$ Heimpel $H$. Tests for diagnosis of preleukemic states. In: Schmalzl F, Hellriegel KP, eds. Preleukemia. Berlin: Springer Verlag, 1979:139-46.

4 Hellriegel KP, Fohlmeister I, Schaefer HE. Aplastic anemia terminating in leukemia. In: Heímpel H, Gordon-Smith EC, Heit W, Kubanek B, eds. Aplastic anemia. Pathophysiology and approaches to therapy. Berlin: Springer Verlag, 1979:47-51.

s Shimamine T, Mori S, Toyama S, Fujii K, Kamiyama R, Matsuya S. Histopathology of bone marrow biopsy in aplastic anemia. Its relation to the prognosis of the patients. Acta Haematol Japan 1981;44: 1306-12.

- Stodtmeister R, Büchmann P. Die funktionell-pathologischen Beziehungen zwischen aplastischer Anämie und akuten leukämien. Ergeb Inn Med Kinderheilkd 1941;60:367-445.

${ }^{7}$ Te Velde J, Haak HL. Histology of bone marrow failure, a follow-up study in aplastic anaemia. In: Heimpel H, GordonSmith EC, Heit W, Kubanek B, eds. Aplastic anemia. Pathophysiology and approaches to therapy. Berlin: Springer Verlag, 1979:15-24.

${ }^{8}$ Fohlmeister I, Schaefer HE, Hellriegel KP, Fischer R. Blood and bone marrow follow-up studies on patients with preleukemic states-observation of different phases of the evolving leukemic process. In: Schmalzl F, Hellriegel KP, eds. Preleukemia. Berlin: Springer Verlag, 1979:16-22.

' Fischer R, Fohlmeister I, Schaefer HE. Pathogenetic relationship between hypoplastic myelopathy and preleukemic syndrome. In: Lennert K, ed. Histopathology of the bone marrow. Stuttgart: G Fischer, 1984:91-6.

${ }^{10}$ Krauze-Jaworska H, Polowska-Kulesza E, Krykowski E. Preleukemic conditions presenting as failure of bone marrow tissue. Pol Tyg Lek 1975;30:23-5.

"Schmalzl F, Konwalinka G, Michlmayr G, Abbrederedis K, Braunsteiner $H$. Detection of cytochemical and morphological anomalies in "preleukemia". Acta Haematol (Basel) 1978; 59: 1-18.

${ }^{12}$ Shimamine T. Pathology of preleukemic state and atypical leukemia. Rinsho Ketsueki 1972;13:323-31.

${ }^{13}$ Kansu E, Erslev A. Aplastic anemia with "hot pockets". Scand J Haematol 1976; 17:326-39.

14 Frisch B, Lewis SM. The bone marrow in aplastic anaemia: diagnostic and prognostic features. J Clin Pathol 1974;27:231-41.

is Alter BP, Potter NU, Li FP. Classification and aetiology of the aplastic anaemias. Clin Haematol 1978; 7:431-65.

${ }^{16}$ Fitchen JH, Cline MJ. Recent developments in understanding the pathogenesis of aplastic anemia. Am J Hematol 1978;5:365-72. 
${ }^{17}$ Heimpel H, Kubanek B. Pathophysiology of aplastic anaemia. $\mathrm{Br}$ J Haematol 1975;31(suppl):57-68.

${ }^{18}$ Bennet JM, Catovsky D, Daniel MT, et al. Proposals for the classification of the myelodysplastic syndromes. Br J Haematol 1982;51:189-99.

${ }^{19}$ Fischer R, Schaefer HE. Präleukämien. Verh Dtsch Ges Pathol 1979;63:154-69.

${ }^{20}$ Greenberg PL. The smouldering myeloid leukemic states. Clinical and biological features. Blood 1983;61:1035-44.

${ }^{21}$ Prchal JT, Throckmorton DW, Carrol AJ III, Fuson EW, Gams RA, Prchal JF. A common progenitor for human myeloid and lymphoid cells. Nature $1978 ; 274-590-1$.

${ }^{22}$ Schaefer HE. Histology and histochemistry in paraffin sections. Verh Dtsch Ges Pathol 1983;67:6-7.

${ }^{23}$ Bryon PA, Gentilhomme O, Fière D. Etude histologique quantitative du volume et de P' hétérogénéité des adipocytes dans les insuffisances myéloides globales. Pathol Biol 1979;27:209-13.

${ }^{24}$ Peto R, Pike MC, Armitage P, et al. Design and analysis of ran- domized clinical trials requiring prolonged observation of each patient. II. Analysis and examples. Br J Cancer 1977;35: 1-39.

${ }^{25}$ Coiffier B, Adeleine P, Viala JJ, et al. Dysmyelopoietic syndromes. A search for prognostic factors in 193 patients. Cancer 1983;52:83-90.

${ }^{26}$ Fohlmeister I, Fischer R, Schaefer HE. Preleukemic myelodysplastic syndromes (MDS): pathogenetical considerations based on retrospective clinico-morphological sequential studies. Anticancer Res 1985;5:179-88.

${ }^{27}$ Burkhardt R. Die Histomorphologie der Knochenmarksinsuffizienz. Blut 1975;16(suppl): 112-34.

${ }^{28}$ Duhamel G, Muratore R, Bryon P, Horschowski N. Histological prognosis in aplastic anemia. Bibl Haematologica $1978 ; 45: 87-95$.

Request for reprints to: Fohlmeister, Institute of Pathology of the University of Koln, Joseph-Stelzmann-Str. 9, D-5000 Köln 41, West Germany. 